\title{
Single molecule FRET characterization of lage ribozyme folding
}

Cardo, L ; Karunatilaka, K S ; Rueda, D ; Sigel, Roland K O

\begin{abstract}
A procedure to investigate the folding of group II intron by single molecule Fluorescence Resonance Energy Transfer (smFRET) using total internal reflection fluorescence microscopy (TIRFM) is described in this chapter. Using our previous studies on the folding and dynamics of a large ribozyme in the presence of metal ions (i.e., $\mathrm{Mg} 2+$ and $\mathrm{Ca} 2+$ ) and/or the DEAD-box protein Mss116 as an example, we here describe step-by-step procedures to perform experiments. smFRET allows the investigation of individual molecules, thus, providing kinetic and mechanistic information hidden in ensemble averaged experiments.
\end{abstract}

DOI: https://doi.org/10.1007/978-1-61779-545-9_15

Posted at the Zurich Open Repository and Archive, University of Zurich ZORA URL: https://doi.org/10.5167/uzh-75262

Journal Article

Accepted Version

Originally published at:

Cardo, L; Karunatilaka, K S; Rueda, D; Sigel, Roland K O (2012). Single molecule FRET characterization of lage ribozyme folding. Methods in Molecular Biology, (848):227-252.

DOI: https://doi.org/10.1007/978-1-61779-545-9_15 


\section{Ribozymes}

Chapter 15

\section{Single Molecule FRET Characterization of Large Ribozyme}

\section{Folding}

Lucia Cardo $^{\mathrm{a}}$, Krishanthi S. Karunatilaka ${ }^{\mathrm{b}}$, David Rueda ${ }^{\mathrm{b}, *}$ and Roland K. O. Sigel ${ }^{\mathrm{a}, *}$

${ }^{a}$ Institute of Inorganic Chemistry, University of Zurich, Winterthurerstrasse 190,

CH-8057 Zurich, Switzerland; *email, roland.sigel@aci.uzh.ch

b Wayne State University, 5101 Cass Ave., Detroit 48202 Michigan, USA; *email, david.rueda@wayne.edu

Running Head: RNA folding by smFRET 


\begin{abstract}
A procedure to investigate the folding of group II intron by single molecule Fluorescence Resonance Energy Transfer (smFRET) using total internal reflection fluorescence microscopy (TIRFM) is described in this chapter. Using our previous studies on the folding and dynamics of a large ribozyme in the presence of metal ions (i.e. $\mathrm{Mg}^{2+}$ and $\mathrm{Ca}^{2+}$ ) and/or the DEAD box protein Mss116 as an example, we here describe step-by-step procedures to perform experiments. smFRET allows the investigation of individual molecules, thus, providing kinetic and mechanistic information hidden in ensemble averaged experiments.
\end{abstract}

Key Words: single molecule, FRET, group II introns, folding, TIRF microscopy, dwell times, DEAD box helicases.

\title{
1. Introduction
}

In the last two decades, bio and nanotechnologies have focused on the development of methods capable of analyzing the structure/function correlation of biomolecules at the single molecule level (1-7). Such methods aim to overcome some of the limitations of bulk experiments. Ensemble averaged experiments yield an average dynamic behavior from a large number of molecules, thus, any unsynchronized, dynamic information about short lived or low populated intermediates can often be lost or misinterpreted. Instead, observing the behavior of single molecules in real time allows the direct analysis of individual folding pathways of different molecules within a large ensemble, including short-lived intermediates, without need for synchronization. Thus, the distribution of different behaviors, rather than the average of these distributions, originating from the contribution of each single observed molecule, can be determined by single molecule experiments. 
Ribonucleic acids (RNAs) are highly versatile systems with a large conformational diversity and intricate folding pathways, which are regulated by metal ions and often by other molecules (mainly proteins) in vivo (8-11). The analysis with 'traditional' methods, such as NMR, CD, UV melting or electrophoresis techniques, provides essential information regarding RNA folding (12-16), but studies of single molecules of RNA performed in the last years have helped to uncover new insights that bulk experiments could not reveal(7).

Single molecule fluorescence resonance energy transfer (smFRET) (17-26) is one of the most widely used methods to observe the folding of single RNAs $(\mathbf{7 , 1 7 , 2 7 - 3 2 )}$. In a standard FRET experiment, the biomolecule of interest is labeled with a donor-acceptor fluorophore pair. Upon excitation of the donor, the efficiency of the energy transfer from the donor to the acceptor is dependent on the distance between the two fluorophores (see Note 1) (1). Thus, FRET can be used as a molecular ruler in the 2-10 $\mathrm{nm}$ distance range, making it an ideal tool to study the structural dynamics and function of biomolecules.

The interference of background signals from various fluorescence sources is one of the main issues in detecting single fluorophores. This can be minimized by measuring highly diluted samples (pM) and using methods that permit the excitation of very small sample volumes $\left(\mu \mathrm{m}^{3}\right)$. Two strategies are commonly employed: confocal microscopy and total internal reflection fluorescence microscopy (TIRFM) (see Note 2 ) $(33,34)$. Here, we focus on the application of TIRFM to detect FRET of single molecules of RNA, using the example of the Sc.ai5 $\gamma$ group II intron ribozyme from Saccharomyces cerevisiae. The folding pathway of this large RNA was characterized by smFRET revealing a new folding paradigm for this large RNA and showing that increasing amounts of $\mathrm{Mg}^{2+}$ not only fold the RNA but also increase the dynamic behavior of the single domains (35). The addition of small amounts of $\mathrm{Ca}^{2+}$ instead leads to the formation of two distinct subpopulations (36) whereas the DEADbox protein Mss 116 can substitute for a large part of $\mathrm{Mg}^{2+}$ and stabilizes the active state (37). 
Group II introns belong to the class of large phosphoryltransfer ribozymes together with group I introns and RNase P RNA. Although the sequence conservation in group II introns is very low, their secondary structure is greatly conserved, usually divided into six subunits, identified as domains D1-D6 (38). D1 is the largest domain and provides the scaffold for the docking of other domains, whilst D5 is the most conserved domain and comprises a large part of the catalytic core. The natural $S$. Cerevisiae (Sc.) ai5 $\gamma$ group IIB intron (yeast mitochondrial intron residing in the coxl gene, $\sim 900 \mathrm{nb}$ ) is one of the best characterized introns of this category (38). Its folding (and consequently its activity) requires high ionic strength in vitro, but splicing in vivo is also assisted by protein cofactors (39-41). The folding dynamics of this intron has been investigated by smFRET by annealing two short DNA strands (15-20 nts) each functionalized with either Cy3 or Cy5 (17) (see Note 3). The synthetic Cy3-DNA and Cy5-DNA oligonucleotides were annealed to a modified version of Sc.ai5 $\gamma$ group II intron named Sc.D135-L14 (Fig. 1) that includes D1, D3 and D5 as well as two 15 nts loops within D1 and D4 whose sequences are complementary to the DNA oligos (see Note 4). Additionally, the 3'-end of the intron is elongated with a sequence complementary to a third DNA strand functionalized with biotin at its 5'-end. Such, immobilization of the RNA can be achieved on the surface of a streptavidin coated quartz slide via the strong streptavidin-biotin interaction.

Before advancing to the smFRET experiments, the correct (and optimal) annealing of Cy3-, Cy5- and biotin-DNAs must be confirmed by native gel electrophoresis. Furthermore, all parameters influencing $\mathrm{R}_{0}$ (and consequently also FRET efficiency) are constants (see Note 1) known for every pair of dyes, except $\kappa^{2}$ that is the factor related to the reciprocal orientation of fluorophores dipoles in the space. The fluorophores are usually assumed to freely rotate without conformational constrictions, meaning that an average value of $\kappa^{2}=2 / 3$ can be applied in calculating FRET efficiency. Fluorescence anisotropy measurements 
$(\mathbf{1 8 , 4 2})$ can be performed to confirm that donor and acceptor are indeed rotating freely, which is the case for $S c . \mathrm{D} 135-\mathrm{L} 14$ (35).

The immobilized and fluorophore-carrying RNA/DNA complex is analyzed on a slide containing a home-built microfluidic chamber placed on an inverted microscope (Fig. 2a,b) $(\mathbf{1 7 , 3 3 )}$. To achieve total internal reflection and visualize the single molecules, the laser excitation beam reaches the slide through a quartz prism placed over the slide itself (Fig. $\mathbf{2 b}$ ). The beam is totally reflected without penetrating below into the sample if the incidence angle is larger than the critical angle $\left(\theta_{\mathrm{c}}\right)$ (see Note 5). Such, an evanescent wave is created which diffuses only shortly $(100-200 \mathrm{~nm})$ below the quartz/solution interface and only the molecules present in that small volume are excited (see Note 6). The fluorescence emission from the sample is collected through an objective and directed into a light-tight box containing a set of dichroic mirrors and lenses that separate the donor and acceptor wavelengths(33). The two signals are then simultaneously detected with a CCD camera as two individual images. The acquisition software allows observation of both the donor and acceptor channel in real time displaying the single molecules as tiny bright dots (Fig. 2c). Each pair of dots (from the donor and acceptor channels) is analyzed with the home-built software to determine the corresponding time trajectories of their smFRET efficiencies. The apparent FRET efficiency (43) is calculated as:

$$
\mathrm{FRET}=\frac{\mathrm{I}_{\mathrm{A}}}{\mathrm{I}_{\mathrm{A}}+\mathrm{I}_{\mathrm{D}}}
$$

where $I_{A}$ and $I_{D}$ are the emission intensities of acceptor and donor, respectively, as integrated from each pair of dots. The image of immobilized fluorescent microspheres (beads) is used as calibration tool to map the two channels. This control is recommended in order to achieve a perfect correlation between two signals in the two channels relative to the same single molecule (33).

In the following we first describe the preparation of Sc.D135-L14 ribozyme by in vitro 
transcription, including the native gel and fluorescent anisotropy control experiments. The smFRET section then includes the description of slide preparation, the execution of smFRET experiment and the data analysis. As an example, the smFRET experiments and analysis of the Sc.ai5 $\gamma$-L14 group II intron construct in dependence of $\mathrm{MgCl}_{2}$ concentration or in the presence of the DEAD box protein Mss116 are described.

\section{Materials}

All chemicals used for preparing buffers and stock solutions are at least puriss p.a. and purchased from usual suppliers. Buffers and solutions are prepared using double distilled autoclaved $\mathrm{H}_{2} \mathrm{O}\left(\mathrm{ddH}_{2} \mathrm{O}\right)$ and subsequently filtered using $0.2 \mu \mathrm{m}$ sterile filters (Filtropur $\mathrm{S}$ syringe filters for volumes up to $100 \mathrm{~mL}$ or Steritops Express ${ }^{\mathrm{TM}}$ PLUS bottle top filters for larger volumes). Polyacrylamide gels are prepared using $\operatorname{AccuGel}^{\mathrm{TM}}$ 29:1 (acrylamide:bisacrylamide; 40\% w/v) stabilized solution from National Diagnostic (UK). Glassware and consumables (eppendorfs, falcon tubes, pipette tips, etc) must be either autoclaved or bought as sterile and DNase/RNase free items.

\subsection{General Stock solutions}

The following stock solutions should be at hand in order to prepare the buffers and solutions listed below:

$1 \mathrm{M}$ Tris $\cdot \mathrm{HCl}, \mathrm{pH} 7.5$ (2-Amino-2-hydroxymethyl-propane-1,3-diol $\cdot \mathrm{HCl}, \mathrm{pH} 7.5$ ); $1 \mathrm{M}$ EDTA, pH 8.0 (ethylenediamine-N,N,N',N'-tetraacetic acid); 5 M NaOH; 500 mM HEPES, pH 7.5 (4-(2-hydroxyethyl)-1-piperazineethanesulfonic acid); $100 \mathrm{mM}$ MOPS, pH 6.0 (3-(Nmorpholino)propanesulfonic acid); $5 \mathrm{M} \mathrm{NaCl}$.

\subsection{Buffers and Solutions for RNA Sc.D135-L14 Transcription}


1. Stock solutions of nucleoside 5'-triphosphates (NTPS). Adenosine 5'-triphosphate (ATP; GE Healthcare), guanosine 5'-triphosphate (GTP; GE Healthcare), cytidine 5'-triphosphate (CTP; GE Healthcare), uridine 5'-triphosphate (UTP; Acros-Brunschwig). About $130 \mathrm{mg}$ of NTP are dissolved in $800 \mu \mathrm{L}$ of $\mathrm{H}_{2} \mathrm{O}$ and $20 \mu \mathrm{L}$ of $1 \mathrm{M}$ Tris $\cdot \mathrm{HCl}$ each. The $\mathrm{pH}$ is adjusted with freshly prepared $5 \mathrm{M} \mathrm{NaOH}$ to $\mathrm{pH} 7.0$ and the solution filled up to $1 \mathrm{~mL}$ with $\mathrm{ddH}_{2} \mathrm{O}$. The exact concentration of the freshly prepared NTP solutions is determined by UV spectroscopy (see Note 7). Aliquots of $\sim 200 \mu \mathrm{L}$ each are then stored at $-20{ }^{\circ} \mathrm{C}$ and used for transcription within a few months.

2. pT7D135-L14 plasmid stock solution. This plasmid encodes the D135-L14 sequence and was stored at a concentration of $\sim 0.3 \mathrm{mg} / \mathrm{mL}$ in $\mathrm{ddH}_{2} \mathrm{O}$ at $-20{ }^{\circ} \mathrm{C}$. Standard digestion with HindIII (or any other specific restriction enzyme) followed by phenol-chloroform extraction is done before in vitro transcription with T7 RNA polymerase. The concentration of the cut plasmid is determined based on its absorbance at $260 \mathrm{~nm}$ (double-stranded DNA average extinction coefficient $\varepsilon=0.020 \mu \mathrm{g} \mathrm{mL} \mathrm{cm}^{-1}$.

3. 10x Transcription buffer ( $p H$ 7.5), 5 mL. $400 \mathrm{mM}$ Tris $\cdot \mathrm{HCl}(\mathrm{pH} 7.5), 400 \mathrm{mM}$ DTT (1,4Dithio-DL-threitol), $100 \mathrm{mM}$ spermidine, $200 \mathrm{mM} \mathrm{MgCl} 2,0.1 \%$ Triton X-100.

4. T7 RNA polymerase. Homemade T7 RNA polymerase $(\mathbf{4 4 , 4 5 )}$ or commercially available T7 polymerase can be used.

5. $100 \mathrm{~mL}$ cold ethanol $\left(-20^{\circ} \mathrm{C}\right)$ and $10 \mathrm{~mL} 5 \mathrm{M} \mathrm{NaCl}$

\subsection{Buffers and Solutions for Polyacrylamide Gel Electrophoresis (PAGE).}

1. Denaturing electrophoresis buffer: 1x TBE buffer $(\sim 700 \mathrm{~mL}$ for preparative gel) prepared from 10x TBE buffer (Tris-borate-EDTA; 0.89 M Tris, 0.89 M boric acid $\mathrm{pH} 8.3$, 20 mM Na 2 EDTA; from National Diagnostic, UK).

2. Denaturing gel loading buffer, $10 \mathrm{~mL} .8 \mathrm{M}$ Urea, $2 \mathrm{mM}$ Tris (pH 7.5), $20 \mathrm{mM}$ EDTA, 
$0.02 \%$ xylene cyanol, $0.02 \%$ blue bromophenol (store at $4{ }^{\circ} \mathrm{C}$ ).

3. Denaturing 5\% PAGE gel solution, $500 \mathrm{~mL}$. $12.5 \mathrm{~mL}$ of AccuGel $^{\mathrm{TM}}$ 29:1 (acrylamide:bisacrylamide; 40\% w/v), 21 g Urea (ultrapure grad, from EUROBIO, France) and $10 \mathrm{~mL}$ 10x TBE (Tris-borate- EDTA) buffer (from National Diagnostic, UK) are diluted with $\mathrm{ddH}_{2} \mathrm{O}$ to $100 \mathrm{~mL}$. Gel solutions are best prepared one day prior to use, filtered after preparation, and stored in the dark at $4^{\circ} \mathrm{C}$. For a $18 \%$ gel use $45 \mathrm{~mL} \mathrm{AccuGel}^{\mathrm{TM}}$.

4. Native gel electrophoresis buffer, 5x stock, $300 \mathrm{~mL}, \mathrm{pH}$ 7.4. $330 \mathrm{mM}$ HEPES, $170 \mathrm{mM}$ Tris $\cdot \mathrm{HCl}(\mathrm{pH}$ 7.5), $15 \mathrm{mM}$ magnesium acetate. The $\mathrm{pH}$ of the solution is adjusted to 7.4 by adding $5 \mathrm{M} \mathrm{NaOH}$. Electrophoresis buffer is used at $1 \mathrm{x}$.

5. Native gel loading buffer, $1 \mathrm{~mL} 60 \%$ glycerol.

6. Native 6\% PAGE gel solution, $100 \mathrm{~mL}$. $16 \mathrm{~mL}$ of AccuGel ${ }^{\mathrm{TM}} 29: 1(40 \% \mathrm{w} / \mathrm{v}), 20 \mathrm{~mL} 5 \mathrm{x}$ native gel buffer diluted with $\mathrm{ddH}_{2} \mathrm{O}$ to $100 \mathrm{~mL}$ total.

7. Gel casting solutions: $500 \mu \mathrm{L}$ of $10 \%$ Ammonium persulfate and $50 \mu \mathrm{L}$ TEMED (tetramethylethylenediamine) for each $100 \mathrm{~mL}$ of gel casting solution (either denaturing or native gel).

8. Elution buffer (pH 6.0), $50 \mathrm{~mL}: 10 \mathrm{mM}$ MOPS, $1 \mathrm{mM}$ EDTA, $250 \mathrm{mM} \mathrm{NaCl}$. The buffer should be kept at $4^{\circ} \mathrm{C}$ and protected in alumina foil after preparation.

\subsection{Buffers and Solutions for smFRET experiments.}

1. Cy3 and Cy5 labeled DNA and T-Biotin-DNA oligonucleotides are purchased from Microsynth, Balgach (Switzerland) or from HHMI Biopolymer/Keck Foundation Biotechnology Resource Laboratory, Yale University, New Haven CT (USA), purified by gel $18 \%$ denaturing polyacrylamide gel electrophoresis, re-dissolved in $200 \mu \mathrm{L}$ of $\mathrm{ddH}_{2} \mathrm{O}$ and stored in the dark at $-20^{\circ} \mathrm{C}$. Concentrations are measured by UV-Vis, using the "nearest neighbour" based method for T-Biotin-DNA (see Note 8), and the following molar extinction 
coefficients for the fluorophore-DNA oligos: $\varepsilon_{\text {Cy3-DNA }}(550 \mathrm{~nm}) 150^{\prime} 000 \mathrm{M}^{-1} \mathrm{~cm}^{-1}, \varepsilon_{\mathrm{Cy} 5-\mathrm{DNA}}$ (647 nm) 250'000 $\mathrm{M}^{-1} \mathrm{~cm}^{-1}$.

2. Catalase from bovine liver (crystalline suspension in water containing $0.1 \%$ thymol, by Sigma) and Glucose Oxidase Type VII (Sigma-Aldrich).

3. $0.5 \mathrm{~mL}$ of $1 \mathrm{mg} / \mathrm{mL}$ Biotinylated BSA solution (ImmunoPure Biotinylated Bovine Serum Albumine by Fisher Thermo Scientific) and $0.5 \mathrm{~mL}$ of $0.2 \mathrm{mg} / \mathrm{mL}$ Streptavidin solution (from S.avidinii, by Invitrogen). Both solutions are stored at $4{ }^{\circ} \mathrm{C}$.

4. Fluorescent beads. FluoroSpheres ${ }^{\circledR}$ carboxylate-modified microspheres $(0.2 \mu \mathrm{m}$, red fluorescent, $2 \%$ in distilled water, $2 \mathrm{mM}$ azide) from Invitrogen are used. Keep at $4{ }^{\circ} \mathrm{C}$ and protected from light (see Note 9).

5. 5x Reaction buffer ( $p H$ 6.9), $10 \mathrm{~mL}: 400 \mathrm{mM}$ MOPS, $2.5 \mathrm{M} \mathrm{KCl}$. Keep at $4^{\circ} \mathrm{C}$ and cover with aluminum foil.

6. T50 buffer (pH 7.5), $1 \mathrm{~mL}: 50 \mathrm{mM}$ Tris $\cdot \mathrm{HCl}, 50 \mathrm{mM} \mathrm{NaCl}$.

If also proteins are present in the reaction mixture, i.e. in the described case Mss116, the following additional buffers and solutions have to be prepared

7. Solutions for preparation of PEG-coated slides: 3-aminopropyltriethoxysilane (Vectabond reagent, Vector Laboratories, Inc., Burlingame, CA), biotin polyethylene glycol succinimidyl carboxymethyl (BIO-PEG-SCM, 3400/5000 MW, Laysan Bio. Inc., Arab, AL) and methoxy polyethylene glycol succinimidyl carboxymethyl (m-PEG-SCM, $5000 \mathrm{MW}$, Laysan Bio. Inc., Arab, AL).

8. 5x Reaction buffer for protein experiments ( $p H$ 7.5), $5 \mathrm{~mL}: 200 \mathrm{mM}$ MOPS, $500 \mathrm{mM}$ $\mathrm{KCl}$. Keep at $4^{\circ} \mathrm{C}$ and cover with aluminum foil.

9. 1x Reaction buffer for protein experiments ( $p H$ 7.5), $5 \mathrm{~mL}: 40 \mathrm{mM}$ MOPS, $100 \mathrm{mM} \mathrm{KCl}$ and $8 \mathrm{mM} \mathrm{MgCl}_{2}$. Filter to sterilize and keep at $4{ }^{\circ} \mathrm{C}$ covered with aluminum foil.

10. $10 \%$ Sugar-buffer for protein experiments ( $p H 7.5), 5 m L: 10 \%$ D-glucose (w/v), $40 \mathrm{mM}$ 
MOPS, $100 \mathrm{mM} \mathrm{KCl}$ and $8 \mathrm{mM} \mathrm{MgCl}_{2}$. Filter to sterilize and keep at $4{ }^{\circ} \mathrm{C}$ covered with alumina foil.

11. $100 \mathrm{mM} \mathrm{ATP} \mathrm{(pH} \mathrm{7),} 1 \mathrm{~mL}$.

\section{Methods}

\subsection{RNA Transcription and Purification}

For a more detailed description see also Section 3.1 of Chapter 16 Metal Ion-RNA Interactions Studied via Multinuclear NMR.

1. $5 \mathrm{~mL}$ in vitro transcription of Sc.D135-L14: Mix cut pT7D135-L14 plasmid $(7.5 \mu \mathrm{g} / \mathrm{mL}$ final concentration in $5 \mathrm{~mL}$ ) with $1 \mathrm{x}$ transcription buffer, ATP, CTP, GTP and UTP (final concentration of $5 \mathrm{mM}$ in $5 \mathrm{~mL}$ for each NTP) and add $\mathrm{ddH}_{2} \mathrm{O}$ up to $4.9 \mathrm{~mL}$. Aliquot the reaction solution into five different eppendorf tubes ( $980 \mu \mathrm{L}$ in each tube) and add $20 \mu \mathrm{L}$ of T7 RNA polymerase to each tube (see Note 10). Shake the reaction mixtures for 4-5 hours at $37^{\circ} \mathrm{C}$ and $300 \mathrm{rpm}$ (overnight is also possible for shorter RNAs).

2. Spin down the insoluble magnesium pyrophosphate resulting from the transcription (1'500 $\mathrm{g}$ for $5 \mathrm{~min}$ ), combine the supernatants into a falcon tube, add $5 \mathrm{M} \mathrm{NaCl}$ (final concentration of $250 \mathrm{mM} \mathrm{NaCl}$ ), and mix with cold ethanol (3x volume). Store at $-20^{\circ} \mathrm{C}$ (at least 6 hours, better overnight) or, alternatively, at $-80^{\circ} \mathrm{C}$ for 1 hour .

3. Centrifuge at $4{ }^{\circ} \mathrm{C}$ and $13^{\prime} 000 \mathrm{~g}$ for $40 \mathrm{~min}$. Separate the white pellets from the supernatant by decantation and dissolve the pellets in as little of $\mathrm{ddH}_{2} \mathrm{O}$ as possible (typically $\sim 2 \mathrm{~mL}$ for a $5 \mathrm{~mL}$ transcription). Keep the solution on ice.

4. Add an equal volume of denaturing loading buffer and purify by denaturing $5 \%$ polyacrylamide gel electrophoresis (PAGE). Usually the product solution of a $5 \mathrm{~mL}$ in vitro transcription is split onto two preparative gels $(28 \times 42 \mathrm{~cm}$ with $1.5 \mathrm{~mm}$ spacers $)$.

5. The RNA bands are located by UV-shadowing, excised and extracted from the gel by the 
crush-and-soak method: Crush the gel into a fine slurry by smashing it through a $10 \mathrm{~mL}$ syringe that has been melted at the tip and puckered again with a needle. Transfer the gel into falcon tubes and soak and shake it in Elution Buffer (3x the volume of the gel) for $4 \mathrm{~h}$ at $4{ }^{\circ} \mathrm{C}$.

6. Separate the eluted RNA from the gel by centrifugation and precipitate with 3 volumes of cold ethanol. Centrifuge at $4^{\circ} \mathrm{C}$ and $13^{\prime} 000 \mathrm{~g}$ for $40 \mathrm{~min}$.

7. After separation from the supernatant, the white pellets are vacuum-dried in a concentrator ("speed-vac"), re-dissolved in as little $\mathrm{ddH}_{2} \mathrm{O}$ as possible and stored at $-20{ }^{\circ} \mathrm{C}$.

8. Measure the absorbance at $260 \mathrm{~nm}$ and use the following equation valid for large RNAs: conc $=\mathrm{A} /(\# \mathrm{NTP} / 100)$, with \#NTP $=637$ for the D135-L14 RNA construct.

\subsection{Control experiments.}

\subsubsection{Native Gel Electrophoresis}

Native gel electrophoresis experiments are performed to verify the correct annealing of the Cy3- and Cy5-DNAs to the RNA under the conditions used in the smFRET experiments.

1. Using the oligonucleotide stock solutions (Section 2.3.), prepare seven samples of $9 \mu \mathrm{L}$ each with 1x Reaction buffer containing (i) Sc.D135-L14 (2 $\mu \mathrm{M})$, (ii) Cy3-DNA (15 $\mu \mathrm{M})$ and (iii) Cy5-DNA (15 $\mu \mathrm{M})$, with the following combinations: (1) only (i), (2) only (ii), (3) only (iii), (4) (ii)+(iii), (5) (i)+(ii), (6) (i)+(iii), (7) (i) $+($ ii) $+($ iii). Concentrations given above are the final concentrations. Use dark (brown) eppendorf tubes for samples preparation.

2. Heat to $90{ }^{\circ} \mathrm{C}$ for 45 seconds.

3. Add $1 \mu \mathrm{L}$ of $1 \mathrm{M} \mathrm{MgCl}_{2}$ (100 mM final concentration) right after heating to $90{ }^{\circ} \mathrm{C}$ and incubate at $42{ }^{\circ} \mathrm{C}$ for $10-15 \mathrm{~min}$.

4. Add $8 \mu \mathrm{L}$ of loading native buffer to each sample and perform electrophoresis using the $6 \%$ native gel $(17 \times 24 \mathrm{~cm})$ at $4{ }^{\circ} \mathrm{C}$ for 2 hours $(15$ Watts). Use a molecular imaging scanner to visualize the bands containing Cy3 and Cy5 (we use a Typhoon molecular scanner) (see Note 
11).

5. Additionally, the gel is stained in a GelRed ${ }^{\mathrm{TM}}$ bath $\left(5 \mu \mathrm{L}\right.$ of GelRed ${ }^{\mathrm{TM}}$, Biotium Inc.

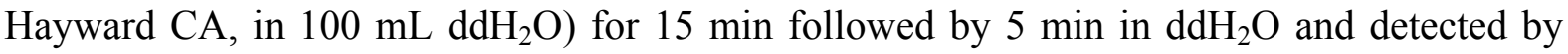
UV shadowing at $260 \mathrm{~nm}$ to visualise possible bands not containing Cy3 and Cy5.

\subsubsection{Fluorescence Anisotropy measurements.}

Fluorescence anisotropy measures the rotational diffusion of fluorescent molecules. Linking a fluorophore to a large biomolecule may affect its ability to rotate freely, thus affecting the values of $\kappa^{2}$ and $\mathrm{R}_{0}$. We performed fluorescence anisotropy measurements $(\mathbf{1 8 , 4 2})$ to confirm that Cy3 and Cy5 are freely rotating when bound to the DNA annealed to Sc.D135-L14 (35) and that $\kappa^{2}=2 / 3$ can be assumed (see Note 1$)$.

Prepare four samples containing Cy3-DNA $(0.15 \mu \mathrm{M})$ and/or Cy5-DNA $(0.5 \mu \mathrm{M}$, total volume of 200 $\mu \mathrm{L}$ each) in the presence and absence of $S c . \mathrm{D} 135-\mathrm{L} 14(0.3 \mu \mathrm{M})$ and fold in $100 \mathrm{mM} \mathrm{MgCl}{ }_{2}$ as described above (Section 3.2.1.).

1. Anisotropy experiments are conducted in a cuvette $(100 \mu \mathrm{L})$ to measure fluorescence polarization using polarized filters on the spectrophotometer. Fluorescence intensities $(I)$ of polarized excitation and emission in vertical $\left(\mathrm{v}, 0^{\circ}\right)$ and horizontal $\left(\mathrm{h}, 90^{\circ}\right)$ positions are recorded in all four possible combinations $I_{\mathrm{vv}}, I_{\mathrm{vh}}, I_{\mathrm{hv}}, I_{\mathrm{hh}}$. The anisotropy value $r$ is calculated as described (42):

$$
r=\frac{I_{v v}-g I_{v h}}{I_{v v}+2 g I_{v h}} \quad \text { with } \quad g=\frac{I_{h v}}{I_{h h}}
$$

If the observed anisotropy values for the free fluorophores are similar to those of the fluorophores attached to DNA in the Sc.D135-L14 RNA-DNA complex is an indication of the free rotation ability of fluorophores in a complex. It is noteworthy that, due their short 
fluorescent lifetimes, the fluorescent anisotropies of $\mathrm{Cy} 3$ and $\mathrm{Cy} 5$ alone in solution are high compared to other commonly used fluorophores such as fluoresceine or rhodamine.

\section{3. smFRET Experiments}

\subsubsection{Instruments}

The folding of D135-L14 ribozyme under optimal in vitro splicing conditions $(500 \mathrm{mM} \mathrm{KCl}$, $80 \mathrm{mM}$ MOPS pH 6.9 and $\left.100 \mathrm{mM} \mathrm{MgCl}_{2}\right)$ or under near-physiological conditions $(100 \mathrm{mM}$ $\mathrm{KCl}, 40 \mathrm{mM}$ MOPS $\mathrm{pH} 7.5$ and $8 \mathrm{mM} \mathrm{MgCl}_{2}$ ) was monitored using a prism-based total internal reflection fluorescence (TIRF) inverted microscope (IX-71, Olympus, Center Valley, PA). Such a setup has recently been excellently described in detail (33) and is thus only shortly summarized here (Fig. 2).

In order to obtain total reflection of the laser beam $(532 \mathrm{~nm}, 3 \mathrm{~mW}$, CrystaLaser GCL-532-L, Reno, NV), the angle of incidence $(\theta)$ on the slide should be larger than the critical angle $\left(\theta_{\mathrm{c}}\right)$. When $\theta>\theta_{c}$, the laser beam totally reflects and creates an evanescent wave at the slidesolution interface that can penetrate a few hundred nanometers to excite the fluorophorelabeled samples (Fig. 2b). The laser beam is introduced through a quartz Pellin-Broca prism (CVI Melles-Griot, Albuquerque, NM) by a mirror (Newport, Irvine, CA). The angle of incidence can be controlled by adjusting the height of the mirror. The reflected laser beam is focused to the prism using a BK7 lens with a $100 \mathrm{~mm}$ focal length (Newport, Irvine, CA).

The donor and acceptor emissions are collected through an inverted microscopic objective and transferred into a light-sealed box through a slit (Fig. 2b). The first dichroic mirror (DM 1, 635DCXR, Chroma, Rockingham, VT) physically separates the donor and acceptor intensities and allows them to pass through lenses (L1 and L2, $200 \mathrm{~mm}$ focal length and 2.0 inch diameter) that amplify the image. The second dichroic mirror (DM 2) recombines the separated donor and acceptor emission signals as side-by-side images onto a high quantum 
yield CCD camera (Ixon+, DV-897E, Andor, South Windsor, CT). The CCD camera amplifies the signals by the highest electron multiplication (EM) gain to maximize the signalto-noise ratio and transfers the digitalized frames to a computer for data analysis (Fig. 2c).

\subsubsection{Preparation of Microscope Slides with a Microfluidic Chamber}

Standard microscope quartz slide $(76 \times 25 \times 1 \mathrm{~mm}$, Finkenbeiner Inc., Waltham, MA, USA) must be modified to create a microfluidic chamber, in which the sample is loaded and immobilized. The slides must be thoroughly cleaned and protected from dust and any type of contamination. A very detailed description has recently been published (33) and is repeated here in slightly different words.

1. Drill two holes into the quartz slides as shown in Fig. 3. Use a hand drill (Dremel 300-N, Racine, WI) held by a work-station (Dremel 220-01, Racine, WI) and diamond drill bits (1.0 mm diameter, Kingsley North, Norway, MI). With a marker, spot the positions of the holes. Drill through the slide placed over a sustaining cylindrical ring immersed in a basin filled with enough water to submerge the slide. The diamond drill bit must penetrate the slide very slowly to avoid slide rupture. Use each diamond bit for 5-6 times only.

2. Clean the slides with a thick paste of powder detergent (Alconox, VWR) and water. Rub slides thoroughly with fingers for at least 20 seconds. Rinse with water keeping wiping with fingers to make sure that all the detergent is removed. Rub and rinse with ethanol and again with $\mathrm{ddH}_{2} \mathrm{O}$. The slides should look perfectly clean at the end of this procedure

3. Place the slides in a beaker containing $100 \mathrm{~mL}$ of autoclaved water, $20 \mathrm{~mL}$ of $30 \%$ ammonium hydroxide and $20 \mathrm{~mL}$ of $30 \%$ Hydrogen Peroxide (work under fume hood ). Boil the solution for $20 \mathrm{~min}$, gently stir with a magnetic bar that does not hit the slides and make sure that the whole surface of the slides is submerged in the solution.

4. Use tweezers to take the slides out of the solution, rinse each of them with water, dry 
them with a Bunsen burner flame (see Note 12) and place them on a metal railing in order to keep the slide uncontaminated (especially the central part of the slides that will hold the fluidic chambers).

5. When the slide cools down, place two stripes of twin-sided adhesive tape parallel to the line defined by the two holes (Fig. 3). Keep about 6-10 $\mathrm{mm}$ distance between the two stripes and precisely place two additional stripes of tape on top of the first ones.

6. Carefully place a cover slip (Microscope cover slides $24 \times 24 \mathrm{~mm}$, Huber \& Co. AG, Reinach, Switzerland) on the tapes, well centered on the slide covering the two holes. Using the top part of the tweezers apply some pressure at the corners to ensure that the cover slip sticks well to slide and is water tight.

7. Cut off the overhanging tape with a razor blade and quickly apply epoxy glue to seal the corners (Fig. 3, see Note 13). When the glue is dry (about 5-10 min) store each slide in a sterilized container (i.e. $50 \mathrm{~mL}$ falcon tubes, see Note 14).

\subsubsection{Preparation of PGE-Coated Slides for Protein Experiments}

In order to minimize nonspecific binding of proteins to the slide surface, polyethyleneglycol (PEG) is used as a passivating agent in single molecule experiments $(\mathbf{3 7 , 4 6 )}$. The procedure below explains the preparation of PEG-coated quartz slides for single molecule experiments with Mss116 and D135-L14 RNA.

1. Clean the slides as described in the first four steps of Section 3.3.2.

2. After drying the slides with a flame, place the slides and coverslips into separate glass coplin jars, filled with $1 \mathrm{M}$ potassium hydroxide $(\mathrm{KOH})$, and sonicate for $\sim 1$ hour.

3. Rinse the slides and coverslips first with distilled water then with methanol. Fill the jars with methanol and sonicate again for $\sim 1$ hour.

4. Clean a beaker with methanol for aminopropylsilation. Mix $1 \mathrm{~mL}$ of 3- 
aminopropyltriethoxysilane reagent (Vectabond) kept in room temperature for $\sim 1$ hour with $100 \mathrm{~mL}$ methanol and $5 \mathrm{~mL}$ glacial acetic acid.

5. Remove methanol and fill the coplin jars containing the slides and coverslips with the previously prepared 3-aminopropyltriethoxysilane solution.

6. Incubate the slides and coverslips for $10 \mathrm{~min}$ and sonicate for $1 \mathrm{~min}$. After sonication, the slides and coverslips should be incubated again for another $10 \mathrm{~min}$.

7. Decant the aminopropylsilane mixture into the appropriate waste container and rinse the slides first with methanol and then with double distilled water.

8. Rinse the slides and coverslips again with methanol and dry them using nitrogen or argon.

9. Prepare the PEGylation buffer by dissolving $84 \mathrm{mg}$ of sodium bicarbonate in $10 \mathrm{~mL}$ double distilled water and filter to sterilize.

10. Prepare PEGylation reaction solution (5 slides): Mix 4-8 mg of BIO-PEG-SCM, $\sim 80 \mathrm{mg}$ of m-PEG-SCM and $320 \mu \mathrm{L}$ of the bicarbonate PEGylation buffer in $1 \mathrm{~mL}$ centrifuge vial. Vortex the solution to dissolve the PEG and then, centrifuge at 10'000 rpm for $1 \mathrm{~min}$ to remove bubbles.

11. In order to perform PEGylation, the slides should be placed in clean PEGylation reaction containers (use a clean pipette tip box and add water in the bottom of the container to maintain a humid environment).

12. Place $70 \mu \mathrm{L}$ of PEGylation reaction solution onto the surface of each slide and slowly place the coverslips onto the slides covering the solution without creating any bubbles between the slide and the coverslip.

13. Close the containers and incubate overnight at room temperature in a dark place to allow the PEGylation reaction to occur.

14. Rinse slides and coverslips with $\mathrm{ddH}_{2} \mathrm{O}$ and dry with nitrogen or argon as previously 
explained.

15. Assemble the slides and coverslips following the steps 5 to 7 as explained in the section 3.3.2.

\subsubsection{Beads Slide Preparation}

The slides containing the bead solution do not need to have drilled holes. These slides can be completely sealed and re-used when necessary.

1. Rinse a cleaned slide (see procedure described in Section 3.3.2) with methanol and dry it under a flux of $\mathrm{N}_{2}$. Place double layers of twin-sided adhesive tape parallel to each other and parallel to the long side of the slide about 6-10 mm apart (Fig. 4a). Place the cover slip (Microscope cover slips $24 \times 24 \mathrm{~mm}$ ) over the centre of the slide creating a microfluidic channel that will hold the beads solution. Cut off the excess of tape with a razor blade.

2. Load $50-70 \mu \mathrm{L}$ of $0.5 \mathrm{M} \mathrm{MgCl}_{2}$ into the chamber with a pipetman. Prepare $1 / 2500$ diluted solution of FluoroSpheres ${ }^{\circledR}$ carboxylate-modified fluorescent beads in water and inject 50-70 $\mu \mathrm{L}$ of this solution into the chamber from the opposite side than used to load the $\mathrm{MgCl}_{2}$ solution.

3. Check if it is possible to see the formed beads using the single molecule setup and whether the image quality and number of beads are satisfactory; see also Section 3.3.5). Seal the microfluidic chamber with epoxy glue (Fig. $\mathbf{4 b}$, see Note 15$)$.

\subsection{5. smFRET Analysis of Sc.D135-L14 in $100 \mathrm{mM} \mathrm{MgCl}$. Sample Preparation and}

\section{Slide Loading.}

The metal ion dependent folding of Sc.D135-L14 was studied using single molecule fluorescence experiments (35). Here, we explain the sample preparation and slide loading to monitor the folding of D135-L14 as an example case for such studies. 
1. Prepare the pipette tips for loading: Cut off $2-3 \mathrm{~mm}$ of the cone end of the $200 \mu \mathrm{L}$ pipette tip with a blade razor. Ensure that the tip tightly fits into the injection hole so that the solutions do not leak during loading but flush out only from the opposite hole (Fig. 3, see Note 16).

2. Prepare a fresh stock of oxygen scavenging solution by mixing $\sim 50 \mu \mathrm{L}$ (powder volume) of glucose oxidase, $12.5 \mu \mathrm{L}$ catalase (see Note 17) and $100 \mu \mathrm{L}$ of T50 buffer. This solution can be stored at $4^{\circ} \mathrm{C}$, but used for no more than 3 days.

3. Prepare $10 \mathrm{~mL}$ of $1 \mathrm{x}$ Reaction Buffer by diluting $2 \mathrm{~mL}$ of $5 \mathrm{x}$ Reaction buffer in $8 \mathrm{~mL}$ of $\mathrm{dd}_{2} \mathrm{O}$ (autoclaved).

4. Prepare a $10 \%$ sugar/buffer solution by dissolving $100 \mathrm{mg}$ D-glucose in $1 \mathrm{~mL}$ (total volume) of $1 \mathrm{x}$ Reaction buffer. Pass the solution through a $0.2 \mu \mathrm{m}$ filter.

5. Prepare $10 \mu \mathrm{L}$ stock solutions each of Sc.D135-L14 (2.5 $\mu \mathrm{M})$, Cy3-DNA, Cy5-DNA and T-Biotin-DNA oligos (100 $\mu \mathrm{M}$ each). Keep the solutions on ice and the dye-DNA oligo solutions protected from light.

6. Prepare solution A: in a dark $200 \mu \mathrm{L}$ eppendorf mix $2.5 \mu \mathrm{L}$ of $\mathrm{ddH}_{2} \mathrm{O}, 2 \mu \mathrm{L}$ of $5 \mathrm{x}$ reaction buffer, $1 \mu \mathrm{L}$ of $\beta$-mercaptoethanol $(\mathbf{1 , 4 7})$ (see Note 18), $2 \mu \mathrm{L}$ of $S c$.D135-L14 stock solution and $0.5 \mu \mathrm{L}$ of each Cy3-DNA, Cy5-DNA and T-Biotin-DNA stock solutions. Vortex, spin down, and heat to at $90^{\circ} \mathrm{C}$ for 45 seconds. Add $1 \mu \mathrm{L}$ of $1 \mathrm{M} \mathrm{MgCl}_{2}$ and incubate at $42^{\circ} \mathrm{C}$ for $15-20 \mathrm{~min}$. Solution A now contains $10 \mu \mathrm{L}$ of folded and labeled RNA at $0.5 \mu \mathrm{M}$ D135-L14, $5 \mu \mathrm{M}$ of each DNAs, 1 x Reaction buffer and $100 \mathrm{mM} \mathrm{MgCl}_{2}$ concentration.

7. Start loading the slide: inject $\sim 80 \mu \mathrm{L}$ of biotinylated BSA solution and incubate for $\sim 10$ minutes to allow for uniform absorption to the slide surface (see Notes 19 and 20).

8. Meanwhile, prepare the oxygen scavenging system (OSS) by mixing $2 \mu \mathrm{L}$ of the stock oxygen scavenging solution, $2 \mu \mathrm{L} \beta$-mercaptoethanol and $196 \mu \mathrm{L}$ of the $10 \%$ sugar/buffer 
solution. Incubate for 15-20 min before use to activate the scavenger system.

9. Wash the microfluidic chamber with $\sim 200 \mu \mathrm{L}$ of T50 buffer to remove the excess of BSA and inject $\sim 200 \mu \mathrm{L}$ of streptavidine solution. Incubate for $\sim 10$ min to optimize biotin binding. 10. In the meanwhile prepare solution $B$ : Mix $1 \mu \mathrm{L}$ solution $A$ and $1 \mu \mathrm{L} \beta$-mercaptoethanol in $98 \mu \mathrm{L} 1 \mathrm{x}$ reaction buffer.

11. Prepare solution $C$ (the final sample solution to be injected): Mix $1 \mu \mathrm{L}$ solution $B$ and 2 $\mu \mathrm{L} \beta$-mercaptoethanol in $197 \mu \mathrm{L} 1 \mathrm{x}$ reaction buffer. The RNA is now $\sim 25 \mathrm{pM}$.

12. Turn off the lights (see Note 21): Wash the microfluidic chamber with $\sim 200 \mu \mathrm{L}$ of $1 \mathrm{x}$ reaction buffer and inject $\sim 200 \mu \mathrm{L}$ solution $C$. Allow binding of the biotynilated RNA to the streptavidin for 7-10 min and inject $\sim 200 \mu \mathrm{L}$ OSS. Equilibrate for $\sim 5$ minutes before taking measurements.

\subsubsection{Sample Preparation and Slide Loading for the Analysis of Sc.D135-L14 in the Presence of Mss116.}

Protein-mediated folding of Sc.D135-L14 can be studied using single molecule fluorescence experiments with the DEAD-box protein Mss116 and ATP (37). This section explains the sample preparation and slide loading to monitor the folding of D135-L14 in the presence of Mss116 and ATP under near-physiological conditions.

1. Prepare solution $A$ by mixing $2.7 \mu \mathrm{L}$ of $\mathrm{ddH}_{2} \mathrm{O}, 2 \mu \mathrm{L}$ of $5 \mathrm{x}$ reaction buffer $(400 \mathrm{mM}$ MOPS pH 7.5 and $500 \mathrm{mM} \mathrm{KCl}$ ), $1 \mu \mathrm{L}$ of $\beta$-mercaptoethanol, $2 \mu \mathrm{L}$ of Sc.D135-L14 stock solution and $0.5 \mu \mathrm{L}$ of each Cy3-DNA, Cy5-DNA and T-Biotin-DNA stock solutions as explained in the section 3.3.5. Heat-anneal the sample for 45 seconds at $90^{\circ} \mathrm{C}$ and incubate at $30^{\circ} \mathrm{C}$ for $15-20$ min after addition of $0.8 \mu \mathrm{L}$ of $100 \mathrm{mM} \mathrm{MgCl}_{2}$ to assure proper annealing and folding. At the end of this step we obtain a $10 \mu \mathrm{L}$ solution containing $0.5 \mu \mathrm{M}$ D135-L14, 
$5 \mu \mathrm{M}$ of all DNA oligos, $100 \mathrm{mM} \mathrm{KCl,} 40 \mathrm{mM}$ MOPS pH 7.5 and $8 \mathrm{mM} \mathrm{MgCl}$.

2. Load the PEG-coated slide with $\sim 80 \mu \mathrm{L}$ of streptavidin solution and incubate for $\sim 10 \mathrm{~min}$ to allow binding of streptavidin to the slide surface.

3. Meanwhile, prepare solution $B$ and solution $C$ as described above (step 9 in section 3.3.5.).

4. Wash the microfluidic chamber with $\sim 200 \mu \mathrm{L}$ of $1 \mathrm{x}$ Reaction buffer and inject $\sim 200 \mu \mathrm{L}$ of solution $C$ (step 3). Incubate for 7-10 min for complete RNA binding.

5. Prepare the OSS with $25 \mathrm{nM}$ Mss116 and 1-2 mM ATP by mixing $2 \mu \mathrm{L}$ of stock oxygen scavenging solution and $2 \mu \mathrm{L}$ of $\beta$-mercaptoethanol using $10 \%$ sugar-buffer solution for protein experiments (final volume $200 \mu \mathrm{L}$ ). Store this solution at $4{ }^{\circ} \mathrm{C}$ until ready to inject.

6. Inject $200 \mu \mathrm{L}$ of the oxygen scavenging system containing $25 \mathrm{nM}$ Mss116 and 1-2 $\mathrm{mM}$ ATP (step 5) and incubate for $5 \mathrm{~min}$.

\subsubsection{Calibration of the Experimental Setup}

In order to obtain the best possible single molecule data, first the instrument needs to calibrated using the fluorescent beads slide (see Section 3.3.4.). This allows to build a map that matches a molecule's signal in the donor channel with its corresponding signal in the acceptor channel.

1. Switch on the CCD camera and the acquisition software and cool the camera to $-80^{\circ} \mathrm{C}$.

2. Place a drop of $\mathrm{ddH}_{2} \mathrm{O}$ on the high numerical aperture water immersion objective $(60 \mathrm{x})$ and place the fluorescent beads slide on the slide holder over the objective with the cover slip facing the objective (see Note 22). Secure the slide with stage clamps.

3. Position the prism onto the slide adding a drop of refraction index-matched immersion oil between slide and prism.

4. Switch the laser on and look for the fluorescent beads through the microscope's eye piece 
using the appropriate filters. Focus the image (see Note 23) and centre the laser beam using the focusing lens placed in front of the prism. The set up is aligned when individual bright dots from isolated beads are visible (see Note 24).

5. To visualize the image onto the $512 \times 512$ pixel EM-CCD camera, switch to the side port. Focus and centre the signal in the observation window using the focusing lens until single beads are clearly visible as bright dots in the donor and acceptor channels (see Note 25). Search for at least 50 sharp and well focused beads, while avoiding large bright dots that may correspond to bead-aggregates.

6. Save $\sim 30$ frames to be further analyzed to generate the image map (see Note $\mathbf{2 6}$ and Section 3.3.8).

\subsubsection{Performing the Single Molecule FRET Experiment}

After the instrument has been calibrated (Section 3.3.6.), proceed with the single molecule analysis of the RNA. The slides with the reaction solution is prepared as described (Section 3.3.5.). Always work in the dark when handling the fluorophore labeled RNA.

1. Five minutes after adding the oxygen scavenging system (step 12, Section 3.3.5) place the slide on the microscope's slide holder and visualize the single molecules as described above (steps 1-8).

2. An EM gain level of 400 is typically used to visualize the Cy3-Cy5 fluorophore pair (see Note 27).

3. Move the stage in order to observe a good set of single molecules and record a set of frames at the desired frame rate. Let the measurement run until photobleaching of the fluorophores is observed (photobleaching time depends on the laser intensity used).

4. Move the stage to another area of single molecules on the same slide to record a new set of frames. From a good slide, 8-10 movies can be collected yielding a large distribution of 
single molecules for data analysis.

\subsubsection{Data Analysis.}

To obtain single molecule time trajectories, the location of single molecule peaks in the donor and acceptor channels is mapped using the image obtained from the immobilized fluorescent beads as a calibration map. The emission intensities of the donor and acceptor fluorophores for every recoded frame are obtained by integrating the corresponding peaks after background subtraction.

Since single molecule experiments can generate significantly large amounts of data, the analysis of single molecule FRET data requires the following specific criteria:

a. Anti-correlated donor and acceptor emission intensities.

b. Single-step photobleaching of fluorophores.

c. Stable emission intensities corresponding to single fluorophore.

Single molecule trajectories of the D135-L14 ribozymes provide valuable information about the folding of introns under different reaction conditions $(\mathbf{3 5 , 3 7 )}$. Each single molecule FRET trajectory represents the folding behavior of an individual RNA molecule exhibiting different FRET states correspond to different structural conformations (Fig. 5a). In order to determine the distribution of different conformational states under given reaction conditions, FRET histograms can be constructed using FRET trajectories from more than 100 molecules, or until convergence (Fig. 5b). Therefore, FRET histograms represent the general effect of different reaction conditions on D135-L14 RNA folding. Under equilibrium conditions, the relative heights of peaks in the FRET histograms can be used to determine the relative stabilities of different conformational states.

In addition, FRET trajectories can be used to obtain valuable kinetic and mechanistic information about the D135-L14 RNA folding pathway using dwell times in each 
conformational state. The dwell time is the amount of time a molecule spends in a given state before switching to the next state. Folding rate constants of D135-L14 can be determined by fitting the dwell-time distribution of each state with an exponential decay function (Fig. 5c,d). Alternatively, the complex single molecule trajectories can be analyzed using a Hidden Markov Model (HMM) for unbiased estimation of the number of distinct FRET states and the folding rate constants among those states $(\mathbf{3 7 , 4 8})$. In addition, the order in which different conformational states appear in the trajectories also enables to distinguish between obligatory folding intermediates from off pathway intermediates.

The resulting folding rate constants for the D135-L14 ribozyme can then be used to calculate RNA folding free energy diagrams, which reveal the ribozyme's folding pathways (37).

\subsubsection{Final Remarks}

Single molecule FRET allows to study the folding and dynamics of even large RNAs and RNA protein complexes, at a so-far unprecedented resolution and provides information that is generally not accessible by bulk experiments. Monitoring the behavior of hundreds of single molecules in real time over several minutes reveals an astonishing diversity in behavior of these individual systems, e.g. short-lived intermediate folding states that are unknown from ensemble averaged experiments. From the individual time trajectories, rate constants of the single folding steps, binding events, possibly catalysis, as well as thermodynamic data can be calculated making this method a very powerful tool widely applicable in modern biophysical research.

Using the example of the Cy3/Cy5 labeled D135-L14 ribozyme derived from the yeast mitochondrial group II intron $S c$.ai $5 \gamma$ group II intron, we here describe all steps starting from RNA transcription and isolation to the recording of single molecule time trajectories and data evaluation as well as the slight modifications applied when investigating RNA protein 
interactions, e.g. in the Mss116-D135-L14 system. Every RNA behaves slightly differently, folds under different conditions and uses different cofactors for catalysis. In addition, the here described setup and methodology are used specifically in our groups and thus depend on each other. Generally, smFRET is not "black-box" technique, but requires hands-on optimization of the mostly self assembled setups as well as adjusting the methodology. Hence, every system has to be thoroughly optimized in order to get the most valuable data, but smFRET allows to readily implementing one's own ideas and directions thus contributing to this fast moving field of biophysical analysis.

\section{Notes}

1. The efficiency of energy transfer is given by $E_{F R E T}=1 /\left[1+\left(R / R_{0}\right)^{6}\right]$, where $R$ is the distance between the two fluorophores and $\mathrm{R}_{0}$ the Förster radius at which $50 \%$ of energy transfer efficiency is observed:

$\left(\mathrm{R}_{0}\right)^{6}=8.8 \times 10^{-28} \kappa^{2} n^{-4} Q_{0} J, \quad J=\int f_{D}(\lambda) \varepsilon_{a}(\lambda) \lambda^{4} \mathrm{~d} \lambda \quad$ where $\kappa^{2}$ is the factor describing the orientation of dipoles, $n$ the refractive index of the medium, $\mathrm{Q}_{0}$ the donor quantum yield in the absence of the acceptor, $f_{D}(\lambda)$ the fluorescence intensity of the donor, and $\varepsilon_{\mathrm{a}}(\lambda)$ the molar extinction coefficient of the acceptor at the same wave length $\lambda$.

2. Confocal microscopy is mostly used for the detection of freely diffusing molecules in solution with low time resolutions because of the avalanche photodiode (ADP) and photomultipliers that are used in this technique (34). In contrast, TIRFM allows the excitation of smaller volumes, which limit the effect of noise background although the signal is detected with charge-couple device (CCD) cameras that work with higher time resolutions.

3. To investigate short RNA sequences $(<60-80 \mathrm{nts})$ by FRET, the two fluorophores are covalently attached by direct insertion during chemical synthesis. In contrast, larger 
constructs are obtained by in vitro transcription by T7 RNA polymerase, which prevents the insertion of modified nucleotides in the middle of a sequence.

4. The underlying construct $S c$.D135 containing only D1, D3 and D5 is the best characterized group II intron construct that contains all necessary units for folding and catalytic activity (38). Control experiments have shown that also Sc.D135-L14 retains equivalent catalytic activity (35).

5. $\theta_{c}$ depends on the indexes of refraction of the quartz slide and buffer solution. The right incidence angle is controlled by regulating the height and distance of the mirror $\mathrm{M}$, as described in detailed in ref $(\mathbf{3 3})$.

6. This setup is known as prism-based TIRF. Alternatively in the objective-based TIRF method, the evanescent wave can be generated through the objective (33). Here, the alignment of the laser beam is more complicate and this strategy is used only when the presence of the prism over the slide is an impediment for the type of experiment to perform.

7. Extinction coefficients of the nucleotides $\left(\mathrm{M}^{-1} \mathrm{~cm}^{-1}\right)$ are: $\varepsilon$ ATP $(260 \mathrm{~nm})=15.4 \cdot 10^{3}, \varepsilon$ $\operatorname{UTP}(260 \mathrm{~nm})=10.0 \cdot 10^{3}, \varepsilon_{\mathrm{CTP}}(270 \mathrm{~nm})=9.0 \cdot 10^{3}, \varepsilon_{\mathrm{GTP}}(249 \mathrm{~nm})=13.7 \cdot 10^{3}$.

8. The extinction coefficients $\varepsilon$ can be estimated using web-based tools, e.g. http://biophysics.idtdna.com/UVSpectrum.html or http:/www.owczarzy.net/abstr11.htm. These calculation tools are based on the "nearest neighbor" method meaning that they take into account not only the extinction of each nucleobase, but also the identity of the neighboring bases $(\mathbf{4 9 , 5 0 )}$.

9. Approximate fluorescence excitation/emission of these beads is $580 / 606 \mathrm{~nm}$. Alternatively, crimson fluorescent FluoroSpheres ${ }^{\circledR}$ carboxylate-modified microspheres (625/645 nm), $0.2 \mu \mathrm{m}, 2 \%$ in distilled water, $2 \mathrm{mM}$ azide, from Invitrogen, can be used.

10. The concentration of homemade $\mathrm{T} 7$ is usually not determined. We concentrate $\mathrm{T} 7$ as much as possible (45). Hence, the optimal amount needs to be optimized in transcription 
trials on an analytical scale (50 $\mu \mathrm{L}$ transcription). Transcription efficiency strongly varies depending on the RNA sequence, plasmid concentration, $\mathrm{T} 7$ batch, $\mathrm{MgCl}_{2}$ and NTP concentration (see also Chapter 16, Section 3.1.).

11. An image of such a native gel experiment is reported in Fig. S2 of the Supporting Information of ref (35).

12. The slides will break easily if held for too long over the flame. Move the slide with the tweezers towards the flame and slowly move it back. Repeat this for about 10 seconds until the slide is dry.

13. Use just the minimal amount of glue to seal the open corners, since excess epoxy glue penetrates into the microfluidic chamber by capillary forces and plugs the holes.

14. Slides can be stored for about 6-8 weeks. Used slides can be recuperated: Soften the glue by boiling the slides in $\mathrm{dd}_{2} \mathrm{O}$ for 20 min or until the glue turns yellowish. Use a razor blade to remove the cover slip and the glue and proceed with the cleaning as described in the beginning of this Section 3.2.2.

15. Calibration of the instrument can be performed with the same beads slide for many weeks as the beads solution in $\mathrm{MgCl}_{2}$ is photostable.

16. The same tip can be used for all the injections described below.

17. Collect the supernatant of the suspension. Alternatively aliquot $16 \mu \mathrm{L}$ of suspension in an eppendorf tube, centrifuge for $30 \mathrm{sec}$ and take $12.5 \mu \mathrm{L}$ of the supernatant.

18. $\beta$-mercaptoethanol quenches the triplet state of the dyes, which helps to achieve a steady light emission minimizing any blinking effects $(\mathbf{1 , 4 7})$.

19. Ideally, both sample preparation and injection into the slide should be carried out in the room set up for single molecule experiments. Keep shut the black curtains of the room during the sample injection, and work close to the microscope thus the slide can be easily transferred for analysis after the injection. 
20. Each solution is slowly and completely injected, carefully avoiding formation of bubbles and allowing the excess of solution to flow out of the opposite hole. After injection remove the tip from the injection hole by keeping down the plunger button of the pipetman to avoid sucking out the solution again.

21. The injection of solution $C$ must occur in a dark room assisted only by low power LED lights. We use USB notebook led lights $(5 \mathrm{~V}, 48 \mathrm{~mA})$ plugged using a 2-port USB charger.

22. Make sure that the slide is resting on the holder and not on the lens of the objective.

23. Take care not to jam the objective into the slide, cracking the slide or, even worse, scratching the lens of the objective.

24. If the image cannot be found, it is recommended to remove the filter and use a lowmagnification objective (e.g. 10x) to pre-align the laser beam on the image centre. Then switch back to the high numerical aperture objective. Make sure that still a drop of water is on the lens.

25. Usually no or only a very low EM gain level $(\sim 20)$ is required to visualize the fluorescent beads.

26. We use the "Run Till Abort" acquisition mode of the Labview program that allows the saving of each picture frame of the movie recorded by the CCD camera at the respective frame rate. This movie containing the sequence of frames is saved to the hard drive as one large *.pma file, which is just a binary file containing all saved frames. This file is then processed with IDL (ITT VIS) scripts to extract the single molecules time trajectories.

27. It is crucial to turn off all lights when the EM gain function is enabled, to avoid fast aging of the CCD camera. 


\section{Acknowledgements}

Financial support by an ERC Starting Grant 2010 (259092-MIRNA to R.K.O.S.), the University of Zürich, the Wayne State University, as well as the NIH (to D.R.) is gratefully acknowledged.

\section{References}

1. Hinterdorfer P., Oijen A. v. (2009) Handbook of Single-Molecule Biophysics. Springer, New York.

2. Cornish P. V., Ha T. (2007) A survey of single-molecule techniques in chemical biology. ACS Chem Biol 2, 53-61.

3. Greenleaf W. J., Woodside M. T., Block S. M. (2007) High-resolution, single-molecule measurements of biomolecular motion. Annu Rev Biophys Biomol Struct 36, 171-190.

4. Kulzer F., Orrit M. (2004) Single-molecule optics. Annu Rev Phys Chem 55, 585-611.

5. Kapanidis A. N., Strick T. (2009) Biology, one molecule at a time. Trends Biochem Sci 34, 234243.

6. Moerner W. E. (2007) New directions in single-molecule imaging and analysis Proc Natl Acad Sci U S A 104, 12596-12602.

7. Karunatilaka K. S., Rueda D. (2009) Single-molecule fluorescence studies of RNA: A decade's progress. Chem Phys Lett 476, 1-10.

8. Fedorova O., Solem A., Pyle A. M. (2010) Protein-facilitated folding of group II intron ribozymes. J Mol Biol 397, 799-813.

9. Lilley D. M. J. (2005) Structure, folding and mechanisms of ribozymes. Curr Opin Struct Biol $15,313-323$.

10. Thirumalai D., Hyeon C. (2009) Theory of RNA folding: from hairpins to ribozymes. In: Walter N. G., Woodson S. A., Batey R. T. (ed) Non-Protein Coding RNAs. Springer, Heidelberg Germany 
11. Lilley D. M. J., Eckstein F. (2008) Ribozymes and RNA catalysis. RCS Publishing, Cambridge UK.

12. Lee M. K., Gal M., Frydman L., Varani G. Real-time multidimensional NMR follows RNA folding with second resolution. Proc Natl Acad Sci U S A 107, 9192-9197.

13. Solomatin S., Herschlag D. (2009) Methods of site-specific labeling of RNA with fluorescent dyes. Methods Enzymol 469, 47-68.

14. Johannsen S., Korth M. M. T., Schnabl J., Sigel R. K. O. (2009) Exploring metal ion coordination to nucleic acids by NMR. Chimia 63, 146-152.

15. Schlatterer J. C., Brenowitz M. (2009) Complementing global measures of RNA folding with local reports of backbone solvent accessibility by time resolved hydroxyl radical footprinting. Methods 49, 142-147.

16. Woodson S. A., Koculi E. (2009) Analysis of RNA folding by native polyacrylamide gel electrophoresis. Methods Enzymol 469, 189-208.

17. Roy R., Hohng S., Ha T. (2008) A practical guide to single-molecule FRET. Nat Methods 5, 507516.

18. Ha T. (2001) Single-molecule fluorescence resonance energy transfer. Methods 25, 78-86.

19. Uphoff S., Holden S. J., Le Reste L., Periz J., van de Linde S., Heilemann M., Kapanidis A. N. Monitoring multiple distances within a single molecule using switchable FRET. Nat Methods 7 , 831-U890.

20. Blanco M., Walter N. G. (2010) Analisis of complex single molecule FRET time trajectories. Methods Enzymol 472, 153-178.

21. Ditzler M. A., Aleman E. A., Rueda D., Walter N. G. (2007) Focus on function: single molecule RNA enzymology. Biopolymers 87, 302-316.

22. Greenfeld M., Herschlag D. (2010) Measuring the energetic coupling of tertiary contacts in RNA folding using Single Molecule Fluorescence Resonance Energy Transfer. Methods Enzymol 472, 205-220. 
23. Kapanidis A. N., Weiss S. (2009) Single-molecule FRET analysis of the path from transcription initiation to elongation. In: Buc V. H., Strick T. (ed) RNA polymerases as molecular motors. RCS Publishing, Cambridge UK

24. Abelson J., Blanco M., Ditzler M. A., Fuller F., Aravamudhan P., Wood M., Villa T., Ryan D. E., Pleiss J. A., Maeder C., Guthrie C., Walter N. G. (2010) Conformational dynamics of single pre-mRNA molecules during in vitro splicing. Nat Struct Mol Biol 17, 504-U156.

25. Bokinsky G., Zhuang X. W. (2005) Single-molecule RNA folding. Acc Chem Res 38, 566-573.

26. Rueda D., Bokinsky G., Rhodes M. M., Rust M. J., Zhuang X. W., Walter N. G. (2004) Singlemolecule enzymology of RNA: Essential functional groups impact catalysis from a distance. Proc Natl Acad Sci U S A 101, 10066-10071.

27. Rueda D., Guo Z. J., Karunatilaka K. (2009) Splicing Mechanisms: Lessons from SingleMolecule Spectroscopy. J Biomol Struct Dyn 26, 48.

28. Weiss S. (2000) Measuring conformational dynamics of biomolecules by single molecule fluorescence spectroscopy. Nature Struct Biol 7, 724-729.

29. Zhuang X. W. (2005) Single-molecule RNA science. Annu Rev Biophys Biomol Struct 34, 399414.

30. Ha T., Zhuang X. W., Kim H. D., Orr J. W., Williamson J. R., Chu S. (1999) Ligand-induced conformational changes observed in single RNA molecules. Proc Natl Acad Sci U S A 96, 90779082.

31. Zhuang X. W., Kim H., Pereira M. J. B., Babcock H. P., Walter N. G., Chu S. (2002) Correlating structural dynamics and function in single ribozyme molecules. Science 296, 1473-1476.

32. Aleman E. A., Lamichhane R., Rueda D. (2008) Exploring RNA folding one molecule at a time. Curr Opin Chem Biol 12, 647-654.

33. Zhao R., Rueda D. (2009) RNA folding dynamics by single-molecule fluorescence resonance energy transfer. Methods 49, 112-117.

34. Vukojevic V., Heidkamp M., Ming Y., Johansson B., Terenius L., Rigler R. (2008) Quantitative single-molecule imaging by confocal laser scanning microscopy. Proc Natl Acad Sci U S A 105, 18176-18181. 
35. Steiner M., Karunatilaka K. S., Sigel R. K. O., Rueda D. (2008) Single-molecule studies of group II intron ribozymes. Proc Natl Acad Sci U S A 105, 13853-13858.

36. Steiner M., Rueda D., Sigel R. K. O. (2009) Ca2+ Induces the Formation of Two Distinct Subpopulations of Group II Intron Molecules. Angew Chem Int Ed Engl 48, 9739-9742.

37. Karunatilaka K. S., Solem A., Pyle A. M., Rueda D. (2010) Single-molecule analysis of Mss116mediated group II intron folding. Nature 467, 935-939.

38. Fedorova O., Zingler N. (2007) Group II introns: structure, folding and splicing mechanism. Biol Chem 388, 665-678.

39. Sigel R. K. O. (2005) Group II intron ribozymes and metal ions - A delicate relationship. Eur J Inorg Chem 2281-2292.

40. Solem A., Zingler N., Pyle A. M. (2006) A DEAD protein that activates intron self-splicing without unwinding RNA. Mol Cell 24, 611-617.

41. Sigel R. K. O., Pyle A. M. (2007) Alternative roles for metal ions in enzyme catalysis and the implications for ribozyme chemistry. Chem Rev 107, 97-113.

42. Lakowicz J. R. (2006) Principles of fluorescence spectroscopy. Springer, New York.

43. Pljevaljcic G., Millar D. P., Deniz A. A. (2004) Freely diffusing single hairpin ribozymes provide insights into the role of secondary structure and partially folded states in RNA folding. Biophys $J$ $87,457-467$.

44. Davanloo P., Rosenberg A. H., Dunn J. J., Studier F. W. (1984) Cloning and expression of the gene for bacteriophage-T7 RNA polymerase. Proc Natl Acad Sci U S A. 81, 2035-2039.

45. Gallo S., Furler M., Sigel R. K. O. (2005) In vitro transcription and purification of RNAs of different size. Chimia 59, 812-816.

46. Lamichhane R., Solem A., Black W., Rueda D. (2010) Single-molecule FRET of protein-nucleic acid and protein-protein complexes: Surface passivation and immobilization. Methods 52, 192200.

47. Rasnik I., McKinney S. A., Ha T. (2006) Nonblinking and longlasting single-molecule fluorescence imaging. Nat Methods 3, 891-893. 
48. McKinney S. A., Joo C., Ha T. (2006) Analysis of single-molecule FRET trajectories using hidden Markov modeling. Biophys J 91, 1941-1951.

49. SantaLucia J. J. (1998) A unified view of polymer, dumbbell, and oligonucleotide DNA nearestneighbor thermodynamics. Proc Natl Acad Sci U S A. 95, 1460-1465.

50. Cavaluzzi M. J., Borer P. N. (2004) Revised UV extinction coefficients for nucleoside-5'monophosphates and unpaired DNA and RNA. Nucleic Acids Res 32, e13. 


\section{Figure Legends}

Figure 1. Secondary structure of the $S c$.D135-L14 ribozyme originating from the wild-type

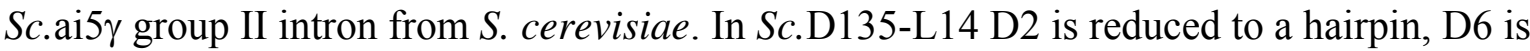
deleted, and two modular loops (L1 and L4) are inserted to permit annealing of DNA-Cy3 and DNA-Cy5 (highlighted in dark). The 3'-end of the intron is elongated with a sequence suitable for the annealing of a biotinylated DNA (also in dark) in order to immobilize the construct on a streptavidin coated slide. The numbering corresponds to the wild type $S c$.ai5 $\gamma$ and tertiary contacts (Greek letters) as well as exon/intron binding sequences (EBS and IBS) are indicated.

Figure 2. smFRET TIRF setup: a) The Cy3/Cy5-Labelled and biotinylated Sc.D135-L14 ribozyme is loaded into the microfluidic chamber of a self made slide coated with streptavidine. b) The mirror $\mathrm{M}$ and the lens $\mathrm{L}$ focus the excitation laser beam to the slide with an angle larger than $\theta_{c}$ to achieve total internal reflection. The resulting evanescent wave excites the molecules within 100-150 nm from the slide surface. The emitted light of the donor $\mathrm{D}$ and acceptor $\mathrm{A}$ is collected through the objective into the light-tight box where the signals from D and A are separated and detected by the CCD camera. c) Single molecules detected through donor and acceptor emission are visible as bright dots in two parallel images. d) Data analysis yields FRET a time trajectory of each single molecule (the shown time trace of $S c . \mathrm{D} 135-\mathrm{L} 14$ at $100 \mathrm{mM} \mathrm{MgCl} 2$ adapted from ref (35)).

Figure 3. Schematic representation of slide preparation with the microfluidic channel, into which the sample is loaded (see also text in Sections 3.3.2. and 3.3.3.). 
Figure 4. Preparation of beads slides. The two sets of double sticky tape are placed parallel to the slide and covered with a cover slip. The solutions are filled from the opposite ends (see also text in Sections 3.3.4.).

Figure 5. Single molecule data analysis. a) A typical FRET trajectory showing the behavior of a single D135-L14 ribozyme in the presence of Mss116 and ATP under near-physiological conditions ( $8 \mathrm{mM} \mathrm{MgCl}_{2}, 100 \mathrm{mM} \mathrm{KCl}$ and $40 \mathrm{mM}$ MOPS pH 7.5). b) FRET histogram showing the distribution of three structural conformations: the extended intermediate state (I), the folded intermediate state $(\mathrm{F})$ and the native state $(\mathrm{N})$. c) D135-L14 minimal folding pathway showing folding rate constants $k_{1,} k_{-1}, k_{2}$ and $k_{-2}$. d) A typical dwell time distribution fit to a single exponential decay to obtain a rate constant for a given transition. Figures are adapted from references $(\mathbf{3 5 , 3 7 )}$. 


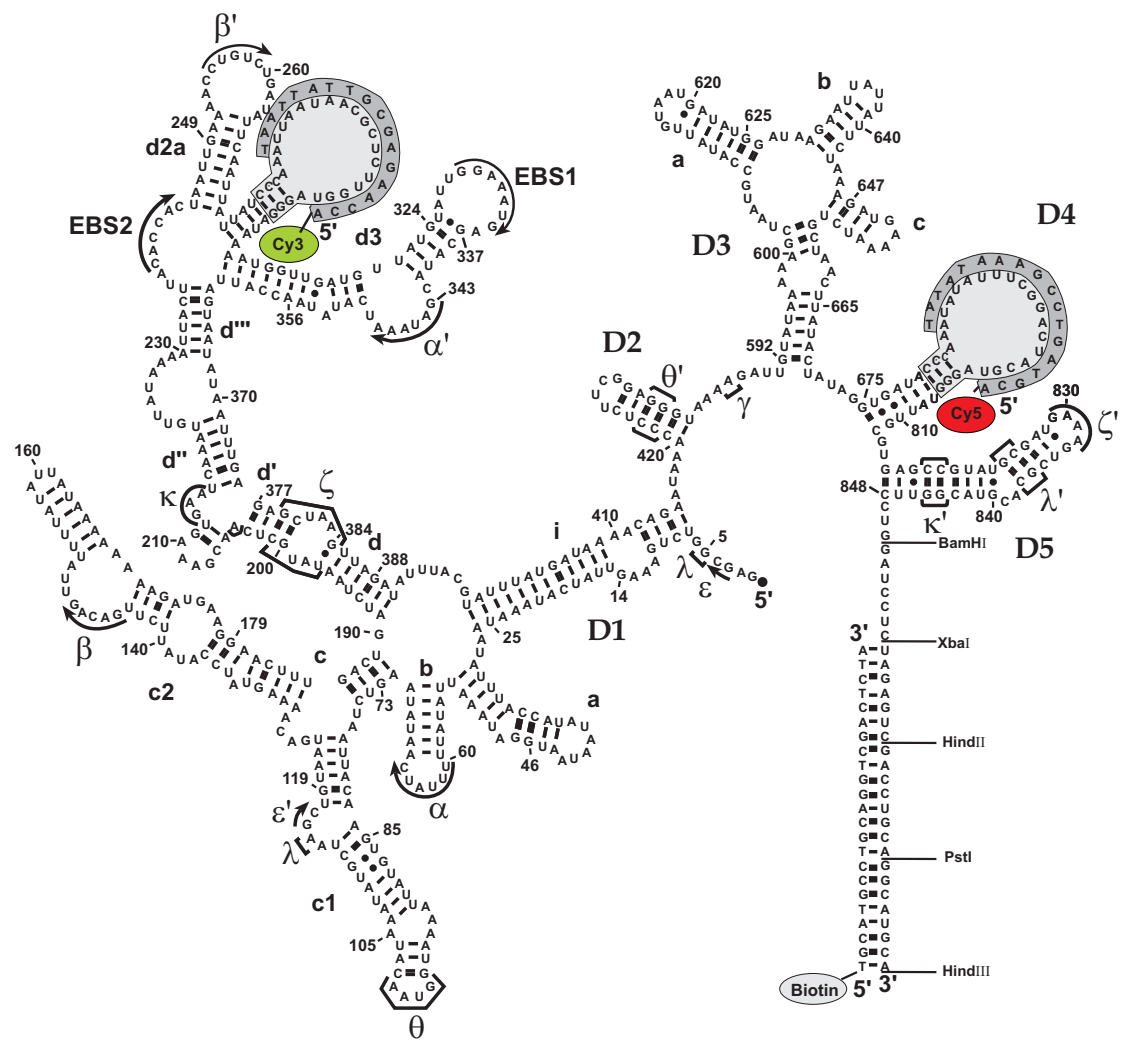




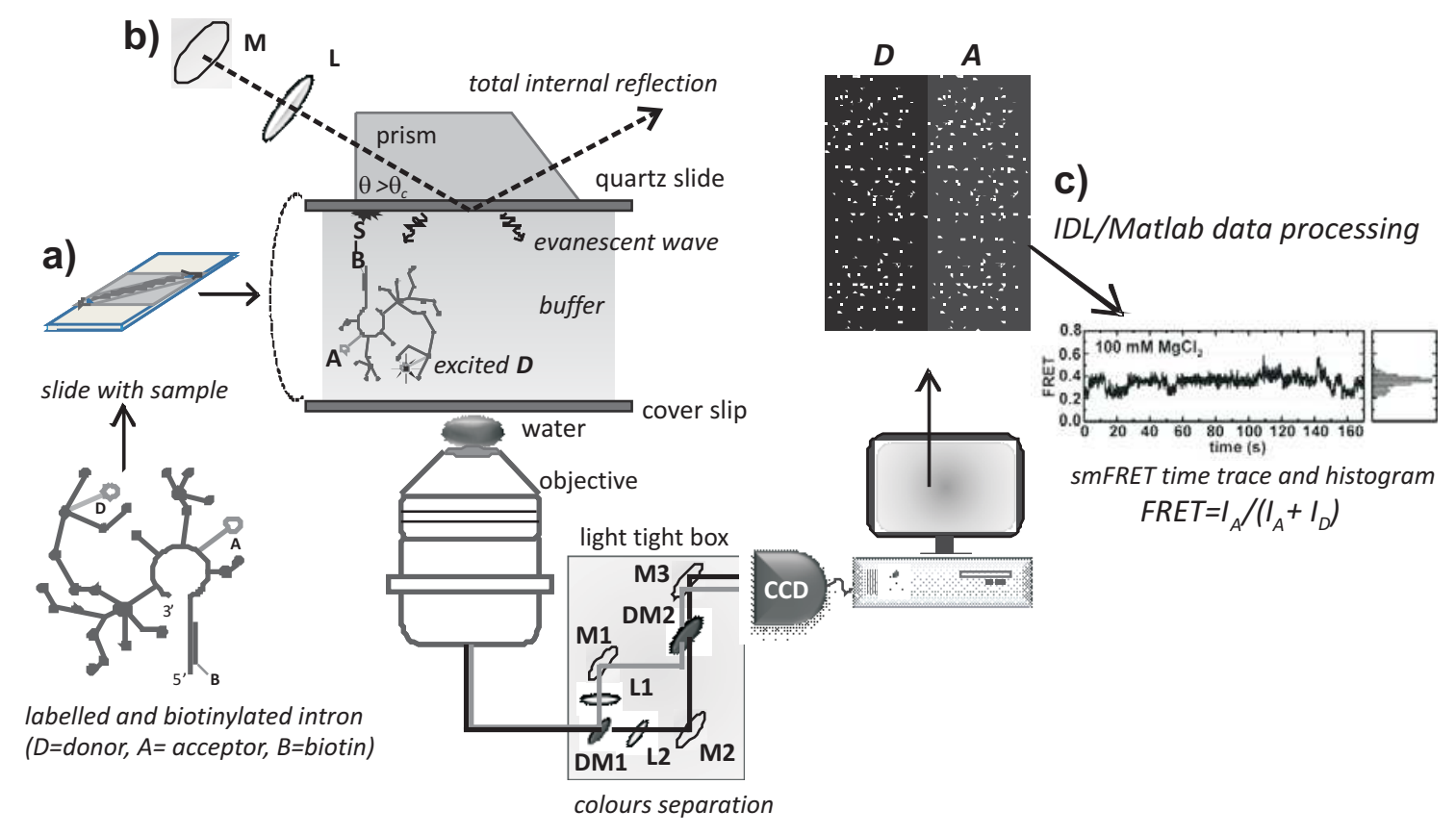




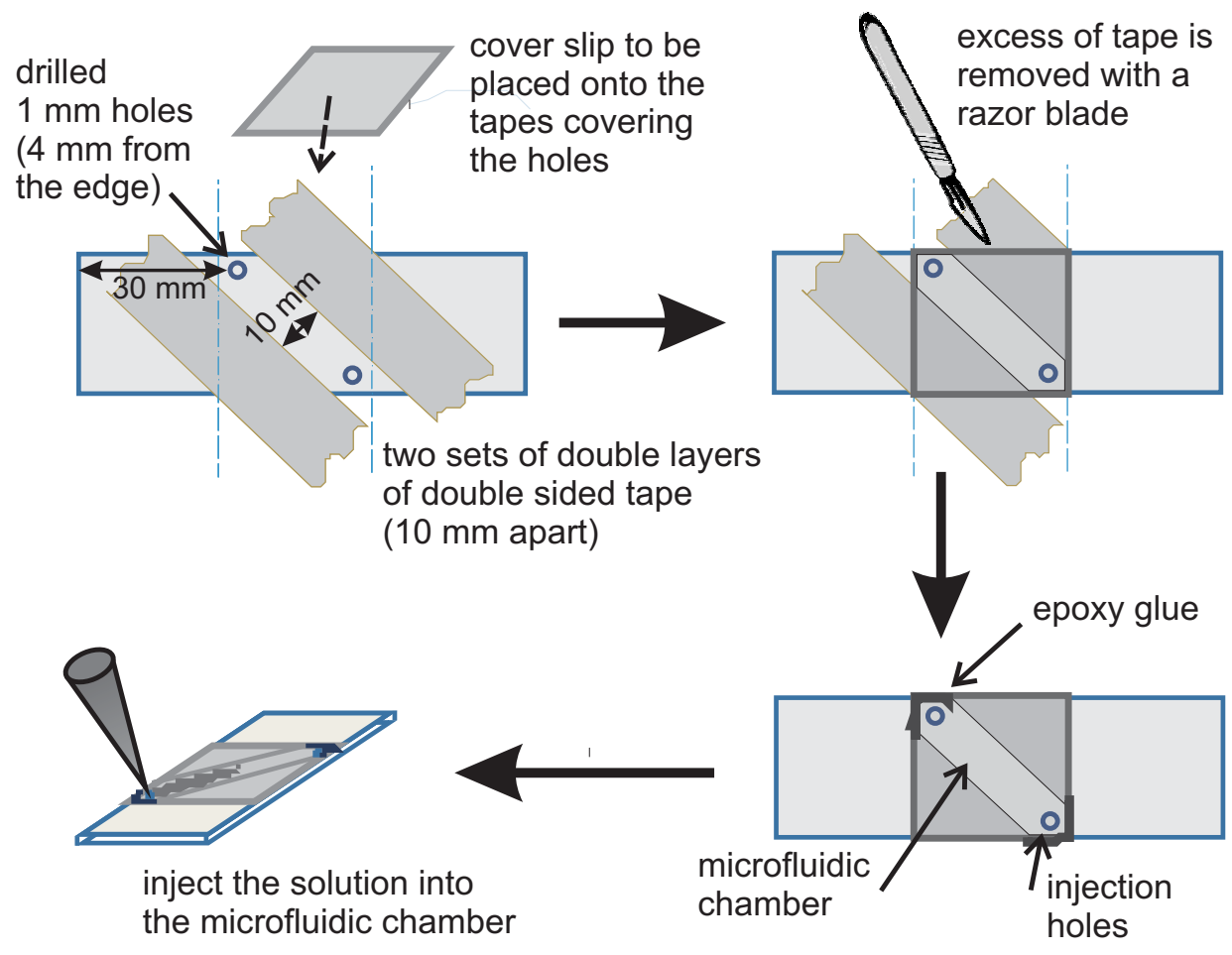


a) double layers of double sided tape with cover slip on top

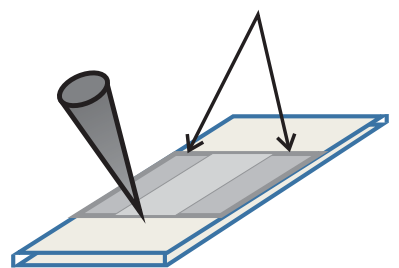

inject the solution into the microfluidic chamber b)

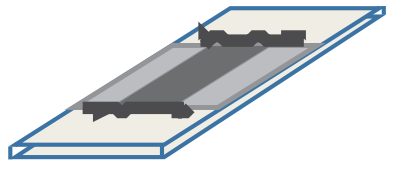

beads slide sealed with epoxy glue 


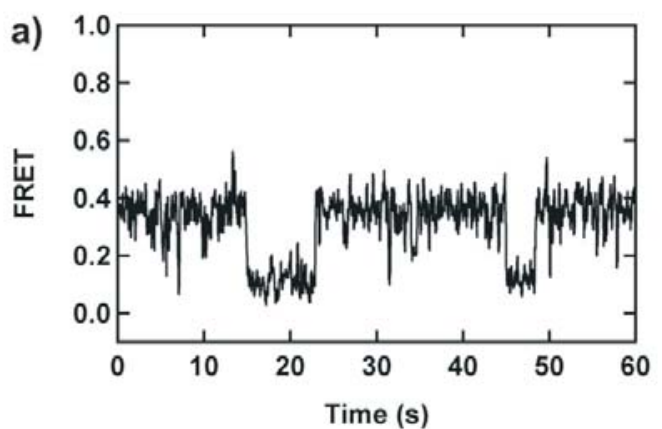

c)

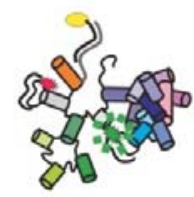

I

Extended Intermediate

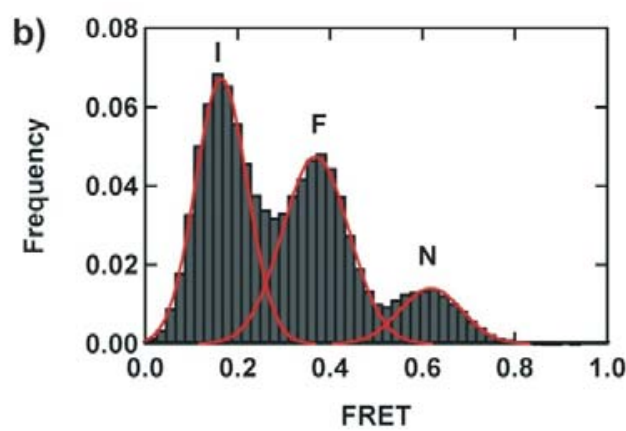

d)

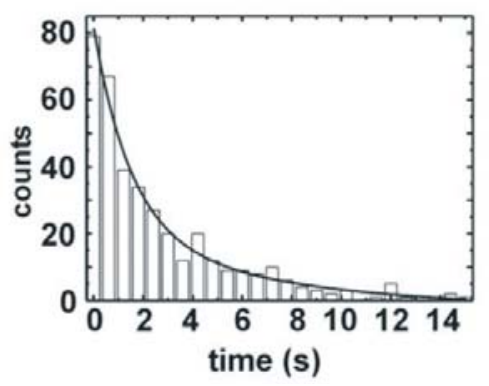

